\title{
Impact of Education on Economic Growth of Pakistan
}

\author{
DOI: http://dx.doi.org/10.18535/ijmeit/v2i11.03 \\ Authors \\ Dr Sabahat Subhan", Muhammad Saqib Gulzar ${ }^{2}$ \\ ${ }^{1}$ Assistant Professor Department of Economics NUML \\ ${ }^{2}$ Student, Department of Economics NUML \\ Corresponding Author \\ Dr. Sabahat Subhan \\ Email: sabahatsubhan@yahoo.com.Ph:03335453272
}

\begin{abstract}
The study explores the impact of education on economic growth of Pakistan by using the Johanson co integration technique by implying Cobb Douglas production function for the period 1970 to 2012. This study analyzes whether the education affects the long run economic growth of Pakistan or not. The empirical analysis shows that there is a long run liaison between the economic growth and the education. Results suggest that independent variables have significant impact on economic growth and these variables are total aggregate production of the economy, total factor of productivity, capital stock, education enrolment and employed labor force.
\end{abstract}

\section{INTRODUCTION}

Education has become essentially important for the development of the country because education is the major source which produces thinkers and innovators, as well as strong, well knows ledged and occupied citizens. Education sustains social mobility and a high level of living standard in the economy. Education is that source which can fight current policy challenges which are maintained by the federal government including democratic regeneration and health care. Furthermore, education institutions and the universities do many researches on the health issues and it provides the best facilities and ideas for modern trade and biased theories as well for the well being of the economy. So we can say that economic growth of Pakistan and access to get the new technologies is belonging to get the education from the different institutions.

At the time of independence in 1947 government assurance towards the education is confirmed by the general enlightening meeting (GEM). This is the $1^{\text {st }}$ step of Government of Pakistan towards clearing the policies, goals and objective for the education. Total eight national education policies in Pakistan are made during the last 58 years. Moreover the policies making for the education system in Pakistan is too much poor because the same policies are repeated again and again by the government, importance of education in Pakistan is not taking serious by the government, failure of the previous policies are unforgettable, yet the target has remained vague up to now.

During the last five decades education area in Pakistan has been suffering from constant as well as strict under investment. Only $1.8 \%$ of GDP is spending on education sector in Pakistan while by the UNESCO it is 4\%. According to the UNDP report Pakistan is that country which is included in the 12 countries which have less than $2 \%$ spending on the education sector. In the recent years education spending is increased significantly specially when we talking about the higher education.

Number of studies has been made on education and economic at national and international level. These include Schultzand beaker (1960), Wolff 
and Gittleman (1993), Siphambe (2000), Brempong (2006), Abbas (2007), De Meulmester et. al. (1995) and ), Rehme (2007). Most of them show the two way association between the education and fiscal development by with the Cobb Douglas production function.

Many of the researchers explain that education and the economic development has the positive relationship. Whenever the education level of a country expands its level of living increases GDP of a country also increases. So that the education sector of any country plays an important role to evaluate the country progress.

This paper has objectives is: find out the association between education and economic growth of Pakistan.

\section{METHODOLOGY}

This study has been conducted to check the impact of education on the economic development of Pakistan. The purpose of this paper is examining the impact of education on economic growth of Pakistan. So we have to view the quantitative data to show the impact of autonomous variables on economic growth.

Whenever we discussed about the empirical studies this will tells us that these studies are begins through the neoclassical model this is introduced with the Solows (1956) and this study is absolute by the Mankiew, Weil and by the Romer in 1992. This model is represented in general form like this

$Y_{t}=A_{t} K_{t}{ }^{\alpha} H_{t}{ }^{\beta} L_{t}^{\gamma} e_{1 t}$

$\mathrm{Y}_{\mathrm{t}}=$ represents the combined Production of the economy

$\mathrm{A}_{\mathrm{t}}=$ Total available Factor Productivity

$\mathrm{K}_{\mathrm{t}}=$ Total Capital Stock

$\mathrm{H}_{\mathrm{t}}=$ Higher Education Enrollment at time $\mathrm{t}$

$\mathrm{L}_{\mathrm{t}}=$ Employed Labor Force

When we take the natural $\log (\mathrm{Ln})$ for to make the linear function

$\mathrm{LY}_{\mathrm{t}}=\mathrm{LA}_{\mathrm{t}}+\alpha \mathrm{LK}_{\mathrm{t}}+\beta \mathrm{LH}_{\mathrm{t}}+\gamma \mathrm{LL}_{\mathrm{t}}+\mathrm{e}_{1 \mathrm{t}}$

In order to see the stationary and non stationary of time series data we will use the ADF. Which is the expansion of Dickey Fuller test? After establishing co integration model an ECM will be used for the short run analysis.

\section{DATA SOURCES}

In this analysis of the study is given sequence data which covers the time epoch of 1970 to 2012. Overall data are collected from economic survey of Pakistan. The erratic $\mathrm{K}_{\mathrm{t}}$ shows the total gross fixed capital formation, $Y_{t}$ is the output which shows the aggregate output measured with the GDP. L $t$ shows the total number of in employment inhabitants during the every year. Hit shows the total enrollments for higher education at institution of advanced education level.

To discover away the collision of education on the economic development, this study occupies the different time sequence econometrics, such as the co integration and the causality. This co integration method is extensively used in the Error Correction Model (ECM) structure, this study also uses the ECM model to analyze the data for short run. In the period of 1969 the Granger residential a test to confirm the causality among the dependent and the independent variables. After that Grangers and Newbolds(1974) shows away so as to here is a chance of imitation causality, to keep away from it, all sequence beneath examination needs to be stationary. Granger (1988) emphasize that, normal tests for causality are applicable only if there is a co integrating association. So that to make sure the co integration properties of the different inconsistent under a concern is essential prerequisite for causality testing in the model.

\section{Unit Root Test}

Before applying the different tests of econometric it is necessary to check the data whether it is appropriate for our study or not. For this purpose we checked data it is stationary or non stationary, if not stationary at which level it becomes stationary. It is necessary for applying the Augmented Dickey Fuller (ADF), that data must stationary at level. 
Findings After the data is stationary checked in the ADF test at level with the help of trend or without the trend. If the data is stationary at the level we apply the Ordinary Least Square (OLS) to find out the results and to see the impact of variables.

If the data are non stationary we will check the data first difference with or without the trend. If our data becomes stationary at first level we apply the co-integration method to find out the results of our variables.

ADF statistical results show that if it is better than the critical value than non stationary and if it is fewer than the critical value than it tends to the stationary.

\section{Johanson Co-Integration}

After testing the stationary of the every time series, and after the assurance that each series of the data is in the same order of homogeneity. After it we have to search for the co integration between the variables, in it particular step this study tells us whether in attendance is a long run association between the variables or not. Granger sense is used to find out the any kind of causality between the variables, it is valid for the two variables more than the two variables we use the other method of co integration which are presented by the different authors.

\section{ESTIMATION OF THE MODEL}

In this section this paper has been analyzed that the education has the impact on economic development in the Pakistan. In this particular chapter we have been considering the unit root separate the stationary on the time series of data.

Now the testing for co integration the unit root test is used only to find the stationarity of data and in this study all variables are finds stationary at a level in trend and intercept. After examining this stationary at the level we apply the order of con integration and Granger test of causality.

The ADF unit root test is applied to the stationary of $Y_{t} \quad K_{t} \quad L_{t}$ and $H_{t}$ at level and the trend and intercept. ADF results are shown at the end of this in the appendices by taking the consideration of trends and intercept in the regression analysis.

\section{Table 1 Stationary Test Results}

\begin{tabular}{|c|c|c|c|}
\hline Variables & ADF statistics & Critical value & Conclusion \\
\hline \multirow[t]{4}{*}{$\mathrm{Yt}$} & -6.635845 & & $\mathrm{I}(\mathrm{I})$ \\
\hline & & -4.192337 & \\
\hline & & -3.520787 & \\
\hline & & -3.191277 & \\
\hline \multirow[t]{4}{*}{$\mathrm{Ht}$} & -6.086705 & & $\mathrm{I}(\mathrm{I})$ \\
\hline & & -4.192337 & \\
\hline & & -3.520787 & \\
\hline & & -3.191277 & \\
\hline \multirow[t]{4}{*}{$\mathrm{Kt}$} & -4.320901 & & $\mathrm{I}(\mathrm{I})$ \\
\hline & & -4.192337 & \\
\hline & & -3.520787 & \\
\hline & & -3.191277 & \\
\hline \multirow[t]{4}{*}{ Lt } & -5.639483 & & $I(I)$ \\
\hline & & -4.205004 & \\
\hline & & -3.526609 & \\
\hline & & -3.194611 & \\
\hline
\end{tabular}

For the stationary we use the unit root test to check the stationarity of dependent variable and the independent variable. To find out the stationary level the ADF value must be greater than the critical value after applying the absolute term. The above data is stationary at level and the $1^{\text {st }}$ difference as well.

Johanson cointegration is used to check the long run relationship between dependent and the independent variables to put them as endogenous 
variables. Here for the co integration first I have taken the $\log$ of all variables then I have been checking the results of co integration.

\section{Table 2 Test for Conintegration}

\begin{tabular}{|l|l|l|l|l|}
\hline Hypothesized & & Trace & 0.05 & \\
\hline No. of CE(s) & Eigenvalue & Statistic & Critical Value & Prob.** \\
\hline None $*$ & 0.577582 & 72.72222 & 63.87610 & 0.0075 \\
\hline At most 1 & 0.342213 & 37.39008 & 42.91525 & 0.1600 \\
\hline At most 2 & 0.258696 & 20.21625 & 25.87211 & 0.2152 \\
\hline At most 3 & 0.176124 & 7.943120 & 12.51798 & 0.2564 \\
\hline
\end{tabular}

Trace test indicates 1 cointegrating eqn(s) at the 0.05 level

$*$ denotes rejection of the hypothesis at the 0.05 level

According to the above situation we reject the null hypothesis when the critical value is less than the trace value. Likely to be in the above table shown that the critical value is less than the trace value we reject the null hypothesis. So that we have seen that in the 1 variable it is shown the long run relationship between the variables.

Table 3 Normalized Con integration Results

\begin{tabular}{|l|l|l|l|}
\hline YT & LT & KT & HT \\
\hline & -0.081158 & -0.266449 & -0.054192 \\
\hline Standard error & $(0.004233)$ & $(0.03440)$ & $(0.01195)$ \\
\hline t-Value & 19.17269 & 7.74561 & 4.53489 \\
\hline
\end{tabular}

For taking the $\mathrm{t}$ value we divided the standard error with the coefficient values. In the above table all values are taken after running the regression in the eviews.

In the above Table 3 it shown that total employed labor force positively affect the economic development of Pakistan with the coefficient values of -0.081158 which leads to development in the economic point of view.

Likewise the total fixed capital formation is also tends the economy to the development side because it is positively affect the economy development of Pakistan so that we reject the null hypothesis and accept the alternative hypothesis for the economy development of Pakistan.

$\mathrm{Ht}$ represents the higher or advanced study in the Pakistan it is also have the positive impact on the development of Pakistan its t value is also shown that it have the positive impact on the development of the Pakistan.

\section{VECTOR ERROR CORRECTION RESULTS}

This particular method is used to find out the short run relationship and the speed of adjustment between the dependent and the independent variables. The given below table shown the speed of adjustment, $\mathrm{t}$ statistics and the standard error.

Table 4 Vector Error Correction Results

\begin{tabular}{|l|l|l|l|l|}
\hline Error Correction: & $\mathrm{D}(\mathrm{YT})$ & $\mathrm{D}(\mathrm{LT})$ & $\mathrm{D}(\mathrm{KT})$ & $\mathrm{D}(\mathrm{HT})$ \\
\hline CointEq1 & -0.689377 & 0.091292 & 2.47111 & -2.1751 \\
\hline Std error & -0.29703 & -0.17671 & -0.93703 & -3.16794 \\
\hline $\mathrm{t}$ Statistics & {$[2.32091]$} & {$[0.51661]$} & {$[2.63718]$} & {$[-0.68660]$} \\
\hline
\end{tabular}

Note:- all of the above negative sign shown the equilibrium level because they are put as an endogenous variables

All of the values of dependent and the independent variables show the speed of adjustment, negative sign shown the conversion forward equilibrium of long run and the positive shown the diversion towards disequilibrium of long run.

\section{CONCLUSION}

In this theory the purpose of our study to find out the most important factors which affect the economic development of Pakistan with higher or advanced level of study. But unfortunately in the case of Pakistan to obtain higher or advanced study is too much difficult because the too much expensive. Budget allocation for the education department from the lower study to higher study is too much low approximately only1429.64 million of the annual budget is allocated for the education department. While the maximum is allocated to the other sector. For the development of higher or advanced education Government of Pakistan have to allocate the extra budget and developed the Government institutions. Only few Public universities Pakistan have in which students are studying while maximum students are in the private institutions and they paying a huge amount of fee due to that they prefer foreign countries for the jobs, highly brain drain is available specially in this case. 


\section{Policy implications}

Pakistan constitution has to provide the equal opportunities regardless the gender biasness. Policy makers should have to make policies for improving the women education and resources are properly available and the check and balance of utilization of these resources. Increase the budget percentage for the necessary education and for the advanced studies that policies are properly implemented. Brain drain is the big problems after obtaining the advanced studies government of Pakistan have maintain policies and restrictions to stop this brain drain level.

\section{REFERENCES}

1. Lucas, R. (1988). On the Mechanisms of Economic Development, Journal of Monetary Economics, vol. 22(1): pp.3-42.

2. Mankiw, N.G., Romer, D., and Weil, D. (1992). A Contribution to the Empirics of Economic Growth, Quarterly Journal of Economics, vol. 107, pp. 407-37.

3. Solow, R.M. (1956). A Contribution to the Theory of Economic Growth, Quarterly Journal of Economics, vol. 70, pp. 65-94.

4. Voon, J.P. (2001). Measuring Social Returns to Higher Education Investment in Hong Kong: Production Function Approach, Economics of Education Review, vol. 20(5), pp. 503-10.

5. World Bank (2010), World Development Indicators, Washington, DC: World Bank.

6. Government of Pakistan, (various) Economic Survey, Ministry of Finance, Economic advisory wing Islamabad.

7. Pritchett, L. (2001). Where has all the education gone?, World Bank Economic Review, vol. 15(3): pp. 367-91.

8. Barro, R, J., (1991), "Economic Growth in Cross-Section of Countries", The Quarterly Journal of Economics, Vol.106, No.2, pp.407-443
9. Lucas R., (1988). On the Mechanics of Economic Development, Journal of Monetary Economics, (22), 1988, 4.

10. Rambaldi, A. N. and H. E. Doran (1996). Testing for Granger Non-Causality in Cointegrated Systems Made Easy, Working Papers in Econometrics and Applied Statistics 88, Department of Econometrics, The University of New England.

11. Social Policy and Development in Pakistan (2003). The State of Education, Annual Review 2002-2003, Social Policy and Development Centre, Karachi, Pakistan, p.4.

12. Solow, R.M. (1956). A Contribution to the Theory of Economic Growth, Quarterly Journal of Economics, vol. 70, pp. 65-94.

13. Solow, R. (1957). Technical change and the aggregate production function, Review of Economics and Statistics, vol. 39, pp. 312-320.

14. Temple, J.R.W. (1999). A positive effect of human capital on growth, Economics Letters, vol. 65(1), pp. 131-134.

15. Temple, J.R.W. (2001). Generalizations that aren't? Evidence on education and growth, European Economic Review, vol. 45(4-6), pp. 905-918 